\title{
Analysis on Countermeasures of the Talent Cultivation Work in Colleges and Universities for the Change in HR Requirement of Taiwan-funded Enterprises under the Background of Industrial Upgrade
}

\author{
Jianping Huang \\ Fuzhou University of International Studies and Trade \\ Fuzhou, China 350200
}

\begin{abstract}
Many successful companies view human resources management from a strategic perspective, regard human resources as a social resource. And human resources (HR) would be a potential capital for them. In the process of talent cultivation, some foreign universities and colleges fully integrate the industrial upgrading and consider the changes in the human resources (HR) required by the company, especially the changes in the human resources of Taiwan-funded enterprises, and adopt corresponding personnel training strategies to promote the training work of talents in colleges and universities.
\end{abstract}

Keywords - talent cultivation in universities; Taiwan-funded enterprises; change in HR demand; countermeasures

\section{INTRODUCTION}

Accelerating innovation, promoting the transformation and upgrading of Taiwan-funded enterprises is an important measure to enhance the market competitiveness of Taiwanfunded enterprises and promote the healthy development of the national economy. Taiwan-funded enterprises' innovation urgently requires high-level technical talents. However, the talent training in colleges and universities are mostly at the theoretical level and cannot fully meet the needs of HR in Taiwan-funded enterprises. For this reason, under the background of industrial upgrading, the training of personnel in colleges and universities is particularly important.

\section{OVERVIEW OF HR CHANGES IN TAIWAN-FUNDED ENTERPRISES}

Under the background of industrial upgrading, when Taiwan-funded enterprises lack human resources planning,

*Fund Project: It is supported by Class A of Fujian and Taiwan Projects of Fujian Provincial Education Department in 2013. Analysis on Countermeasures for the Change of HR Requirement of Taiwan-funded Enterprises in the Work of Talent Cultivation in Colleges and Universities under the Background of Industrial Upgrade (Project No.: JA13569S)
Taiwan-funded enterprises will bear higher costs. Incomplete human resources planning will lead to vacancies that cannot be filled, and the loss of efficiency is expensive, especially the standard method. It should retrain personnel to fill vacancies. Sometimes, similar positions will be withdrawn in one department and recruited in another, which may result in redundancy and the dismissal of newly hired personnel.

\section{THE ROLE OF HUMAN RESOURCES PLANNING FOR TAIWAN-FUNDED ENTERPRISES}

The lack of human resources planning for Taiwan-funded enterprises will make it difficult for employees to make career or personal development plans. As a result, some capable and motivated people may find themselves at a higher level.

\section{A. To Formulate Strategic Objectives and Development Plans for Taiwan-funded Enterprises}

The senior management of Taiwan-funded enterprise is in the process of formulating strategic objectives and development plans, as well as selecting a decision-making plan, especially the situation of human resources. Human resource planning enables senior management to understand and analyze the current situation of various talents within the Taiwan-funded company, as well as the possibility of internal promotion of resource training or external recruitment within a certain period of time, which is conducive to target decision-making and strategic planning.

\section{B. To Change the Unreasonable Status of Human Resource Allocation within Taiwan-funded Enterprises}

The formulation of the plan is based on the analysis of the status quo of human resources and the prediction of human resources in the future. It is to explore the potential of human resources. Its improvement plan is not limited by the existing conditions. It requires leaders to broaden their horizons, improve the structure and quality of personnel, 
make the existing human resources play the biggest role, and provide manpower guarantee for the development of Taiwan-funded enterprises. The task of human resources planning is to plan what kind of talents will be required for Taiwan-funded enterprises in the future, how many different types of talents will be needed, and where they will be located. Once they are needed, they can be found in time.

\section{To Guide Career Transfer}

Due to the constant rise of new technologies, the renewal and mobility of people's occupations has accelerated. And career transfer has become an inevitable result of social development. In the context of industrial upgrading, the breadth and depth of career transfer are unpredictable in the past. Therefore, in formulating human resources planning, Taiwan-funded enterprises must analyze the trend of labor transfer, study the countermeasures and plan in advance. Otherwise, it will cause the labor force to fail to make transfer in time.

\section{To Control Labor Costs}

The labor cost of Taiwan-funded enterprises depends on the distribution of personnel in the organization in different positions and at different levels. In different development periods, the distribution of personnel of Taiwan-funded enterprises is different, and labor costs have also changed. In the initial stage of the organization, the proportion of low-job personnel is relatively large. And the labor cost is relatively low. With the development of Taiwanese-funded enterprises, the wage costs increase due to the increase in the level of personnel positions. At the same time, they are subject to wage rigidity and price increases. The impact of control factors, labor costs often exceed the ability of Taiwan-funded enterprises to withstand. A good human resource plan can predict the development situation of the company in the future, adjust the personnel structure in a planned and stepby-step manner, make the distribution of personnel more reasonable, avoid the occurrence of redundant personnel and faults, and reduce waste and inefficiency in the allocation of human resources. Labor costs are reasonable and feasible.

\section{E. To Mobilize the Enthusiasm of Employees}

Human resource planning is a plan for Taiwan-funded enterprises and employees. Many Taiwan-funded enterprises are faced with a steady stream of employee turnover. On the surface, Taiwanese-funded enterprises cannot provide employees with excellent treatment or promotion channels. This actually shows the gaps or deficiencies in the human resources planning of Taiwan-funded enterprises. The formulation of corporate human resources planning can promote Taiwan-funded enterprises to match their own development and needs with the development and needs of employees. Based on human resource planning, Taiwanfunded enterprises guide employees in their career design and development. It would allow them to clearly understand future job vacancies and see their own development prospects. And then, it would actively strive for and mobilize their enthusiasm and creativity. It would create a good working atmosphere.

\section{COUNTERMEASURES TO PROMOTE TALENT CUlTivation IN COLLEGES AND UNIVERSITIES}

\section{A. To Reconstruct the "Capabilities-oriented" Curriculum System}

Under the background of industrial upgrading, the changes in HR needs of Taiwa-funded enterprises are oriented toward the needs of service jobs and the enhancement of professional abilities, and the top-level design role of each professional talent training program is fully utilized. It should break the original framework of the discipline, closely integrate with industrial upgrading, design and optimize the curriculum structure in accordance with industrial development needs and professional qualification standards, and reconstruct the curriculum system.

1) To break the barriers of professional training courses and set up talent training platform: Under the framework of personnel training in colleges and universities, we will integrate related professional basic courses, main courses, core courses, professional skills application and experimental practice courses, and the basic professional courses. And it would achieve a unified platform for personnel training. For example, the financial management major builds a platform course that focuses on basic financial knowledge.

2) To practice teaching and ability training throughout the entire process of personnel training: In accordance with the corporate principle of "focusing on the use of students and highlighting students' practical abilities", it should combine the characteristics of talents with talents training requirements. And it would increase the proportion of practical teaching. Each major has a comprehensive curriculum or curriculum module in the personnel training program. Each specialty sets 6-8 professional core courses, strengthens the support of the professional core curriculum for professional core competence, and implements the reflection between curriculum system and knowledgeability-quality structure according to the professional training standards.

\section{B. To Promote the "Output-oriented" Reform of Personnel Training Model}

It should strengthen the ties with Taiwan-funded enterprises, conduct in-depth investigations, scientifically make self-position, and closely match the needs of social and economic development and the needs of industry and enterprise development, and further look for gaps in talent cultivation. In accordance with the actual needs of HR in Taiwan-funded enterprises, it should boldly introduce vocational qualification standards and industry standards, revise and improve the application-oriented personnel training standards, further improve the road map for career development, and formulate training standards for applied talents with Taiwan-funded enterprises. They should jointly improve personnel training programs, jointly build a curriculum system and teaching content, jointly build a practice training base, jointly organize a teaching team, 
jointly implement the training process, and jointly evaluate the quality of training. The participation rate of key professional courses in Taiwan-funded enterprises reaches $100 \%$. The personnel training standards and actual needs of the development of Taiwanese capital industry are realized.

\section{To Construct "Work Process-oriented" Practical Teaching System}

In the context of industrial upgrading, it would strengthen the relevance and systematicness of the experimental teaching content of various specialties. It requires that each professional should organically link the original single-item and static experimental projects when designing and cultivating programs, the work process between the upstream and downstream positions of Taiwan-funded enterprises, and business processes. And then, it would build a professional practice teaching system.

\section{1) To reform practice teaching system}

a) Setting up practical teaching projects:According to the professional training requirements and professional characteristics of each professional, it should adhere to the cross progress of theoretical teaching and practical teaching. Through the professional practice experimental teaching system, it would ensure that each professional experimental practice link scores account for more than $30 \%$ of the total credit, in which comprehensive, design experiments account for more than $80 \%$ of the experimental practice credits. It should promote excellent dissertation (design) nurture plans, promote students to complete graduation thesis (design) or other practical projects during practice training, and guide students to select topics based on actual problems and actual needs of industry companies. It would ensure that the thesis (design) really solves the real problem. It would enhance the ability to practice innovation. At the same time, a complete practical teaching plan and syllabus have been formulated. And practical curriculum standards have been formulated to ensure that the teaching objectives of experimental practice are achieved.

b) Designing practical teaching content based on "work process": Based on the business process and project progress of Taiwan-funded enterprises, it should combine the characteristics of Taiwan-funded enterprises faced by professional services. The company has developed and set up specialized experimental courses or experimental projects. It carefully designs and covers basic verification experiments, composite design experiments, and virtual simulation comprehensive experiments, quality improvement and development of innovative experimental design of the curriculum system. It requires professional teachers to participate in the construction of practical teaching system. Also, it would set up a special topic experimental project for the actual industry.

2) Building a practical teaching platform: Through the construction of experimental practice sites inside and outside the school, a practical teaching platform of "imitative integration" was constructed. And practice operations were concretely implemented. Based on real-life cases and statistical data, students were provided with a comprehensive, comprehensive, experiential practical teaching platform and learning practice environment.

a) Inter-school experiment production: It should increase investment in practical teaching of various specialties, build and renovate a batch of laboratories, practice training bases, and sharing platforms of practical teaching resources to ensure the quality of experimental teaching. The colleges should attract industrial companies with advanced training equipment, high-quality training projects and experienced practical trainers to enter the campus. The real situations, real tasks, and real positions are introduced into the campus. And business processes are mainly established. In the simulation environment, various business units and functional positions within and outside of Taiwan-funded enterprises are organically linked to establish a set of simulation models to simulate the actual business operations and management activities. And it would achieve the integration of practical training and production practices, classrooms and positions. With organic combination of systematic management theory and process operation practice, each experimenter can deeply understand the relationship between the local and the overall part, understand their position in the process of the functional position and take the initiative to plan their own experimental process and experimental steps. They would independently complete relevant business processes and other relevant experimentation experiments. It should integrate scattered knowledge into interoperable system knowledge. And it would achieve the simultaneous improvement of theoretical level and application capability.

b) The off-campus internship teaching: Focusing on the characteristics of economic development in the current region and combining the practical teaching needs of schools, we will focus on the development and maintenance of a number of in-depth cooperation enterprises. We will combine points to form a model in which teaching will be conducted alternately within enterprises and schools. The students will be encouraged to enter Taiwan-funded enterprises for field production practices. They would deeply and completely contact with the operational process of Taiwan-funded enterprises, early access to new technologies, new processes, and new business. And it would promote the mastery and application of professional knowledge and professional skills.

c) To promote the combination of training and competition: Under the background of industrial upgrading, according to the HR needs of Taiwanese-funded enterprises, the colleges would select related disciplines competition projects, and organically combine competition content and experimental courses. And the colleges should guide students to think independently, solve problems independently, cultivate students' logical thinking and teamwork skills, and improve students' professional interest 
and practical application ability. Then, it would stimulate students' sense of innovation and develop students' abilities.

\section{CONCLUSION}

Under the background of economic globalization and industrial upgrading, the global market has become more and more closely linked. Accordingly, the HR needs of Taiwanese-funded enterprises have also moved from closed to open. This has broken through the traditional awareness of corporate boundaries and geographical boundaries. Also, it would foster global ideas and teamwork spirit. The spirit and implementation of effective cross-cultural training and management will become challenges that the human resources management of Taiwan-funded enterprises will inevitably face. Therefore, the training of talents in universities and colleges should aim at countermeasures, which will benefit the needs of talents in Taiwan-funded enterprises.

\section{REFERENCES}

[1] [1] Ma Chunjing. Faculty construction of applied universities of Fujian province with the cooperation between Fujian and Taiwan[J].Modern Vocational Education, 2016(04) 马春景. 以闽台合 作为契机的福建应用型高校师资队伍建设 [J]. 现代职业教 育, 2016(04)

[2] [2]Mao Shujie. A preliminary exploration of the interactive talents cultivation model of "three parties of the Bank, School and Enterprise" [J]. Journal of Wuhan Metallurgical Management Institute. 2015(06) 毛述劼. “校企校两岸三方” 互动人才培养模式初探 [J]. 武汉治金管理干部学院学报.2015（06）

[3] [3]Hu Jiaoyang. The construction of teacher-student resource sharing platform in the joint training of talents project of the "schoolenterprise" in Fujian and Taiwan[J]. Times Education. 2015(01) 胡娇 阳.闽台 “校校企” 联合培养人才项目中的师生资源共享平台的 建构[J].时代教育.2015(01) 